DOI: 10.34015/2523-4552.2020.4.02

УдК 355.9

\begin{abstract}
Колб О. Г., доктор юридичних наук, професор, заслужений юрист України, професор кафедри політології, управління та державної безпеки Волинського національного університету імені Лесі Українки ORCID: 0000-0003-1792-4739
\end{abstract}

Пирожик О. В., радник ректора ПВНЗ «Академія рекреаційних технологій і права», депутат Волинської обласної ради

\title{
ДЕПУТАТСЬКЕ «ВОЛОНТЕРСТВО» ЯК КОРУПЦІЙНИЙ ЧИННИК В ОРГАНАХ МІСЦЕВОГО САМОВРЯДУВАННЯ ТА ОДНА ІЗ ЗАГРОЗ НАЦІОНАЛЬНІЙ БЕЗПЕЦІ УКРАЇНИ
}

У статті розглянуто питання, пов'язані з волонтерською діяльністю депутатів місцевих рад, визначені проблеми, які детермінують у зв'язку з цим вчинення корупційних правопорушень, а також розроблені відповідні науково обгрунтовані і апробовані зарубіжним досвідом заходи, спрямовані на усунення причин та умов, що сприяють зазначеному суспільно небезпечному явищу.

Ключові слова: депутат; волонтерство; корупція, органи місцевого самоврядування; інформаційна безпека; національна безпека; національні інтереси; правопорушення.

В данной научной статье рассмотрены вопросы, связанные с волонтерской деятельностью депутатов местных советов, определенные проблемы, которые детерминируют в связи с этим совершение коррупционных правонарушений, а также разработаны соответствующие научно обоснованные и апробированные зарубежным опытом меры, направленные на устранение причин и условий, способствующих указанному общественно опасному явлению.

Ключевые слова: депутат; волонтерство; коррупция, органы местного самоуправления; информационная безопасность; национальная безопасность; национальные интересы.

Постановка проблеми. Останнім часом світові ЗМІ знову рясніють повідомленнями про те, що чи не найбільше зло українського суспіль- ства - тотальна корумпованість влади, яка, мовляв, наскрізь пронизує всі владні ешелони - від верхів до низів. До прикладу, 45-й президент США 
Дональд Трамп у жовтні 2020 року заявив, що призупиняв надання Україні коштів через глибоку корупцію, за якою Україна оцінювалась як одна $з$ найкорумпованіших країн у світі. Як зауважував Д. Трамп, йому не подобається давати гроші країні, яка настільки корумпована [1]. Таким чином, потенційні загрози від тотальної корупції у воюючій країні він поставив у один ряд із тими реальними загрозами, які нашій державі несе «гібридна війна» 3 Російською Федерацією. Вказані інформаційні посили не лише й надалі послаблюють і без того не високий міжнародний імідж влади нашої держави та посилюють загрози посягань на їі інформаційну безпеку, але й підвищують рівень викликів національній безпеці України. У той самий час спростувати подібні наративи чи щось серйозне їм протиставити в силу об'єктивних і суб'єктивних причин носії української влади не беруться, не можуть чи не хочуть.

У цьому контексті слід критично оцінити оптимістичні заяви представників Transparency International Ukraine, що в Індексі сприйняття корупції за 2020 рік Україна піднялася на 3 бали та 333 балами посіла 117 місце серед 180 країн. Адже 33 бали за минулий рік так само набрали Єгипет, Есватіні (Свазіленд), Непал, Сьєрра-Леоне та Замбія, який виявилися нашими сусідами в рейтингу. Якщо це й успіх, то дуже тимчасовий і нетривкий, а таке сусідство невтішне. Тим більше, що ключовим показником Індексу $є$ кількість балів, а не місце в рейтингу. Мінімальна оцінка (0 балів) означає, що корупція фактично підміняє собою державу, максимальна (100 балів) свідчить, що корупція майже відсутня в житті сус- пільства [2]. Бали України передусім зросли завдяки запуску Вищого антикорупційного суду та перезапуску Національного агентства 3 питань запобігання корупції. Водночас, як показує практика, залишається ряд серйозних ризиків, які можуть суттєво відкинути Україну назад у сфері протидії корупції. Це, зокрема, затримка $з$ судовою реформою, постійний тиск на антикорупційні інституції, а також спроби порушити й нівелювати досягнення у сфері публічних закупівель. Актуальними залишаються також питання безкарних нападів на активістів.

Разом із тим, звинувачення у «наскрізній» корумпованості української влади нівелює межу між двома пластами їі носіїв, одні з яких виконують свої функції за кошти платників податків, а інші - на громадських засадах, тобто на безоплатній основі. В Україні це: у першому випадку органи державної влади (причому безвідносно до поділу на різні гілки державної влади), у другому - представники органів місцевого самоврядування, абсолютна більшість яких (у статусі депутатів місцевих рад) виконують владні функції фактично на волонтерських засадах, тобто реалізують свої повноваження на засадах депутатського «волонтерства» (Волонтерство, або волонтерська діяльність (від фр. volontaire (доброволець); лат. voluntas (вільне волевиявлення); лат. volō (бажання, намір) добровільна безкорислива суспільно корисна діяльність).

Неоплачуваність депутатської роботи в місцевих радах зумовлює системні ризики та спокуси, які часто штовхають цих суб'єктів влади до дій чи діянь, пов'язаних із корупці$є ю$, у т.ч. з отриманням неправомір- 
ної вигоди - як своєрідної «подяки» за надані й отримані внаслідок депутатської діяльності «послуги». Відтак, як свідчить практика, звідси й побутує думка, що за корупцію в нас карають тих, хто не «накрав» стільки отриманих неправомірних вигод, щоб ними «відкупитися» від покарання, а тих, хто «краде» мільйонами і вагонами, - правоохоронна система або не бачить, або ж правосуддя їх милує. Звісно, це - образно кажучи, хоча усталена громадська i суспільна думка потребує того, щоб детальніше проаналізувати причини і умови, які призводять чи стимулюють зазначених суб'єктів до таких дій. А, крім того, ці обставини детермінують існуючий стан справ 3 означених питань і впливають на формування негативного іміджу України в світі та продукують загрози, що посягають у зв'язку з цим на національну безпеку.

Отже, слід визнати, що в наявності - складна прикладна проблема яка потребує невідкладного вирішення.

Постановка завдання. Виходячи з цього, метою даної наукової статті $€$ обґрунтування необхідності підвищення ефективності запобіжної діяльності з так званим депутатським «волонтерством», як одним із корупційних чинників в органах місцевого самоврядування та загрозою національній безпеці України. А головним завданням - розробка аргументованих заходів, спрямованих на усунення, нейтралізацію, блокування тощо детермінант, які обумовлюють вчинення корупційних правопорушень із боку вказаної категорії суб'єктів корупційних діянь.

Аналіз останніх досліджень і публікацій. Вивчення наукових, на- вчально-методичних та інших тому подібних видань (посібників, коментарів до законів, рекомендацій тощо) показало, що проблемами боротьби 3 корупцією досить активно та продуктивно займаються такі учені, як О. М. Бандурка, Ю. В. Баулін, І. В. Борисов, І. Г. Богатирьов, В. В. Голіна, Б. М. Головкін, В. К. Грищук, О. М. Джужа, I. М.Копотун, О.Є.Користін, О. М. Костенко, М. І. Мельник, О. М. Литвинов, О. М. Литвак, В. О. Навроцький, П. Л. Фріс, В. І. Шакун, М. І. Хавронюк та інші науковці. Поряд із цим, з урахуванням сьогоднішніх соціально-політичних, воєнних, фінансово-ресурсних та інших реалій, що склалися в нашій державі, розробка проблем, що стосуються забезпечення національної безпеки України, є актуальною і такою, що має теоретико-прикладне значення. Більш того, на доктринальному рівні депутатське «волонтерство» не стало предметом наукових досліджень, що знижує рівень діяльності по запобіганню корупції та негативно впливає на ії ефективність і результативність, тож необхідність розробки зазначеної проблематики є очевидною.

Виклад основного матеріалу. Якщо проаналізувати сукупність правопорушень антикорупційного законодавства в органах місцевого самоврядування України, їх можна умовно поділити на ті, в яких очевидно відсутній, або ж безумовно наявний усвідомлений умисел до корупційних діянь. За логікою, відсутність умислу у вчиненні такого діяння мала би обмежуватися дисциплінарною або ж адміністративною відповідальністю за таке правопорушення, натомість наявність умислу - передбачати покарання відповідно до 
кримінального законодавства України. Це - загальний підхід, з якого, без сумніву, є винятки, зважаючи на індивідуальний характер кожного правопорушення. Як видається, в цій проблемі надзвичайно важливим $\epsilon$ сукупний аналіз мотивів, якими керуються в обох загальних випадках суб'єкти таких правопорушень. Зокрема, неусвідомлене неподання або несвоєчасне подання декларацій суб'єктом декларування, як це передбачено Законом України «Про запобігання корупції» [3], як свідчить практика, не мало би формувати основний масив загальної статистики такого роду правопорушень, оскільки в абсолютній більшості зазначене правопорушення не тягне за собою якихось правових наслідків. До того ж, нерідко такі правопорушення допускаються суто з технічних причин чи від незнання (що, втім, не звільняє від відповідальності) змісту Закону.

Як показали результати вивчення відповідних емпіричних матеріалів, щороку депутатів місцевих рад систематично притягують до відповідальності і навіть судять за несвоєчасне подання декларацій про доходи. Формально - це правопорушення, фактично ж - фіксація саме такого роду правопорушень формує кількісну статистику нібито активної боротьби з корупцією. Адже на формальне притягнення такого роду правопорушників до відповідальності витрачається значно більше фінансових та організаційних ресурсів правоохоронних і судових органів, аніж реальна шкода від їх вчинення (здебільшого вона - взагалі відсутня) чи фінансові відшкодування від присудженого покарання (як правило, це штрафи в мінімальних розмі- pax). Так, Національне агентство 3 питань запобігання корупції (далі НАЗК) за перший рік своєї роботи 3 початку створення (15 серпня 2016 року) склало та подало до суду стосовно депутатів місцевих рад 28 протоколів про адміністративні правопорушення за несвоєчасне подання декларацій (близько 10,1\% від загальної кількості 276 адмінпротоколів) [4]. I це при тому, що, за даними Урядового порталу, на той час у структурі НАЗК уже функціонувало 7 департаментів, управління бухгалтерського обліку, відділ правового забезпечення та декілька секторів, а в складі агентства працювало 238 осіб. Тим часом, починаючи 3 2019 року (з часу існування Реєстру декларацій), НАЗК вдалося притягнути до відповідальності за умисне неподання декларацій чи декларування недостовірних відомостей 97 осіб, із яких 17 - призначено покарання у вигляді позбавлення волі $(17,5 \%)$ на термін від року до року та 6 місяців із позбавленням права обіймати посади, пов'язані із виконанням функцій держави та місцевого самоврядування строком на 12 роки [5]. Крім цього, статистика показує, що до Єдиного державного реєстру осіб, які вчинили корупційні або пов'язані з корупцією правопорушення (Реєстру корупціонерів), притягнутих до відповідальності за статтею 366-1 Кримінального кодексу (КК) України [6], тобто за умисне неподання чи подання завідомо недостовірних відомостей у декларації, протягом усього часу існування Реєстру внесено 42 депутати місцевих рад (43,3\% від усієї кількості).

Для розуміння того, що саме формує статистику звітності НАЗК, варто навести кількісний перелік 
категорій, які потрапили до Реєстру корупціонерів: 42 депутати місцевих рад; 15 посадовців органів Державної кримінально-виконавчої служби України (ДКВСУ); 11 посадовців державних та комунальних підприємств; 8 державних службовців (зокрема працівники Державної фіскальної служби, Пенсійного фонду України, Держгеокадастру, районних державних адміністрацій, державні виконавці); 6 посадовців органів Національної поліції України; 6 посадовців органів Державної служби надзвичайних ситуацій; 3 суддів; 3 посадових осіб місцевого самоврядування; 2 лісників; 1 народний депутат України [5].

Звертає на себе увагу той факт, що за результатами розгляду справ у 64 випадках $(65,97 \%)$ суди призначали покарання у вигляді громадських робіт на строк 150-240 годин із позбавленням права обіймати посади, пов'язані з виконанням функцій держави або місцевого самоврядування строком на 1-2 роки. I найчастіше таке покарання застосовувалося саме до депутатів місцевих рад. Тоді як до суддів і держслужбовців (16,49\% випадків) - штраф від 2500 до 3000 неоподатковуваних мінімумів доходів громадян (тобто від $\sim 42500$ до 251000 гривень) із позбавленням права обіймати посади, пов'язані 3 виконанням функцій держави та місцевого самоврядування строком на 1-2 роки [5]. Цілком очевидно, що затрачені державою ресурси на притягнення до відповідальності депутатів місцевих рад не виправдовують компенсації від понесених за такі правопорушення покарань.

Як встановлено у ході даного дослідження, на сьогодні у відкритих джерелах неможливо отримати повної інформації щодо того, який відсоток від усіх адмінпротоколів, складених за несвоєчасне подання чи подання недостовірних відомостей у декларації, доведений до суду, а також який відсоток викладених у них епізодів знайшов підтвердження в судових інстанціях. У зв'язку з цим можна припустити, що насправді він мізерний, про що, власне, свідчать результати аналізу роботи органів місцевого самоврядування Волинської області, а саме: таких протоколів стосовно депутатів місцевих рад щороку складають десятки, а притягують до юридичної відповідальності одиниці осіб. Якщо ж вести мову про запобіжну діяльність у сфері вчинення можливих правопорушень чи проступків, пов'язаних із корупційними діяннями, ставлячи завдання щодо вироблення системних механізмів 3 метою запобігання корупційним правопорушенням в органах місцевого самоврядування, то вкрай важливо узагальнити дані щодо усвідомленої мотивації дій самих суб'єктів можливого корупційного діяння, враховуючи іiї соціально-правову природу та соціально небезпечні наслідки у вигляді потенційної загрози національній безпеці України [7].

Як показують результати цієї наукової розробки, така мотивація розпочинається вже з моменту подачі відповідних документів кандидатами в депутати місцевих рад, від розуміння того, для чого ця особа іде в депутати, якщо така робота $\epsilon$ неоплачуваною і фактично здійснюється на волонтерських засадах. Одна річ, якщо таке волонтерство - це поклик чи стан душі, інша - бажання здобути певний соціальний статус чи скористатися шансом для самореалі- 
зації як особистості. Ще інша - бажання отримати 3 цього статусу якісь матеріальні вигоди або додаткові блага, а також, нерідко - реалізувати його з метою отримання завідомо неправомірної вигоди. Як вбачається зі змісту інформації, розміщеної в матеріалах журналістського дослідження аналітиків «Української правди» (надалі - УП), один раз на 5 років Україна шукає майже 160 тисяч таких волонтерів [8]. Саме вони після виборів мають стати депутатами місцевих рад - і ця «армія» має 5 років безкоштовно працювати для громади.

У зв'язку з цим постає логічне питання: чи $\epsilon$ типовим в усталеному розумінні «волонтерство» депутатів місцевих рад із тим, яке фактично сформувалось та існує в теперішніх українських реаліях? Результати вивчення цієї проблеми в Україні показують, що після початку збройної агресії Російської Федерації проти України 2014 року, наша країна сформувала свій громадсько-суспільний феномен вказаного вище волонтерства, тобто діяльності, яка в умовах фактичної відсутності боєздатних Збройних Сил, спільно з добровольчим рухом, бійцями добровольчих батальйонів по суті, врятували Україну від неминучої поразки, втрати значних ресурсів та територіальної цілісності. Цей приклад волонтерства, поєднаний із жертовністю бійців добровольчих батальйонів - своєрідний подвиг представників фронту i тилу, беззаперечно, гідний поваги. Крім цього, він може бути взірцем для інших націй, як у найважчу годину можна і треба захищати свою державу і свою землю у боротьбі 3 більш боєздатним ворогом, відстоювати свої національні інтереси та протидіяти реальним загрозам національній безпеці.

Саме тому пасіонарність (від лат. passio - пристрасть, пристрасність) таких волонтерів може дати ствердну відповідь на запитання: чи можна таким волонтерам довірити представляти інтереси інших співвітчизників у місцевих радах? Як видається, такі волонтери справді могли би стати найкращими захисниками прав своїх виборців у місцевих радах, але, на превеликий жаль, не в сьогочасних політико-олігархічних українських реаліях, що підтверджуються і результатами виборів, і подальшим аналізом складу та соціальної структури депутатів місцевих рад в Україні. Перший із доказів вищезазначеного - відповідь на питання, чи багато сьогодні сучасників бойових дій та волонтерів $є$ депутатами в місцевих радах. Як правило, у місцевих радах їх - одиниці. Одні не подають свої кандидатури на вибори до цих рад, не маючи необхідних фінансових, організаційних чи медійних ресурсів, а інші - не в змозі здолати ставлеників олігархічних політструктур. Тому реальні волонтери в українських реаліях - як «білі ворони» у загальній структурі депутатів місцевих рад, що не дає змоги нейтралізувати у зв'язку з цим потенційні впливи і загрози, а також усунути джерела, які посягають на національну безпеку.

Як встановлено в ході даного дослідження, насправді - абсолютна більшість із тих, хто за нинішніх реалій стають депутатами місцевих рад в Україні, - фактично $€$ лжеволонтерами. Адже численні політико-олігархічні структури, які завели їх у місцеві ради, систематично мотивують цих осіб на «правильну» 
депутатську діяльність, у т.ч. і матеріально. Здебільшого - здійснюють це за «потрібні» олігархам голосування. При цьому не є принципово: чи така мотивація є постійною і системною, чи ситуативною та систематичною. Ї̈̈ суть від цього не змінюється, позаяк на волонтерських засадах насправді працює неспівмірна меншість депутатів. У той самий час, більшість депутатів місцевих рад у зв'язку з цим є лже-волонтерами, що тільки підвищує рівень потенційних загроз і викликів національній безпеці України. На жаль, у теперішніх реаліях існування в Україні такої ж самої лже-еліти зазначена ситуація не $€$ дивною, скоріше - закономірною. Але це не означає, що такий стан змінити не можна. При цьому, неважко здогадатися, хто чинитиме при такому підході найбільший спротив, позаяк олігархічним колам, які поєднують владу і гроші, не потрібні справжні депутати-волонтери. Їм зручніше мати своїх, слухняних «ручних-пригодованих», руками яких і руйнуються системи балансів влади, противаг і стримувань, а фактично - відбувається руйнація основ нашої державності та національної ідентичності.

Отже, можна зробити висновок, що таке депутатське «волонтерство» із волонтерством реальним, в існуючих українських реаліях, має мало спільного (як правило, просто не має нічого спільного). Як слушно зауважують із цього приводу журналісти УП, треба бути наївним, щоб вірити у те, що ми знайдемо 160 тисяч порядних і відданих людей, які в інтересах громади будуть голосувати за землевідведення, доступ до річок та озер, розподіл бюджетних коштів. Навіть 50\% від цієї кількості знайти на во- лонтерських умовах строком на 5 років нереально. Саме тому в місцеву владу йдуть цілими династіями для того, щоб дерибанити найцінніші i невідновлювані ресурси громади [8] («дерибан» - процес поділу або розподілу загальносоціальних або просто цінних речей в колі обраних або серед «своїх»). Таку ситуацію необхідно кардинально змінювати - від верхів до низів. Але якщо на центральному рівні це навряд чи вдасться змінити, не змінивши олігархічної економічної моделі, то на місцевому - можна запропонувати цілком легітимні шляхи і механізми, як змінити ситуацію, у т.ч. реформувавши низові ланки влади - місцеве самоврядування. I найбільш універсальний шлях - через вивчення позитивного іноземного досвіду та внесення відповідних змін у чинне законодавство України, зокрема в частині навіть не протидії, а саме запобігання корупції [9], що, в свою чергу, дасть змогу встановити більш дієві запобіжники корупційним діянням та загрозам національній безпеці.

Цікавим у зв'язку з цим зарубіжний досвід 3 означеної проблематики, зокрема США. Як показали результати його вивчення, досвід цієї країни дає однозначне вирішення даної проблеми: всяка праця має бути оплачуваною. Саме тому, у США робота депутатів усіх рівнів - платна. Як зауважує з цього приводу міський голова громади Спрінгфілда, у них депутати на рік отримують десь 15 тисяч доларів. Хоча, це не постійна робота і для американських реалій не надто великі гроші. Для порівняння, вчитель у США заробляє дещо більше - 60 тисяч доларів на рік, а зарплата мера становить майже 130 тисяч доларів на рік, тобто дві 
річні зарплатні вчителя [10]. У свою чергу, у ФРН депутати місцевих рад отримують символічну компенсацію тільки за участь у сесійних та комісійних засіданнях. Це - погодинна компенсація. Вона може сягати до 500 євро на місяць та 17,5 євро - за кожне засідання комісій. Подібні підходи практикують також інші країни Західної Європи, зокрема Іспанія. Навіть у сусідній Польщі місцевим депутатам платять, щоправда - не сталу суму, як у США, а за кількість проведених депутатом на сесії голосувань [11]. У той самий час, як показує практика, в Україні нерідко йдуть у владу, аби лобіювати інтереси власного бізнесу. Відповідним чином такі депутати вибудовують і пріоритети власної діяльності. Більше того, у місцевих радах депутати«прогульники» нерідко саме тим i намагаються виправдати свою неякісну роботу, що їм за неї не платять. Або ж - надмірною зайнятістю за основним місцем роботи, де вони отримують стабільну зарплатню. То чи можна при таких підходах у масштабах всієї України забезпечити належну захищеність національних інтересів?

Без сумніву, ефективність місцевого депутата напряму залежить від якості його роботи. А якість роботи більшості депутатів місцевих рад за існуючої владної системи, як показує практика, часто $є$ незадовільною. Іноді один депутат може виконувати роботу якісніше від декількох. Саме тому в усіх перерахованих вище країнах кількість депутатів, робота яких так чи інакше оплачується, у розрахунку на кількість населення $\epsilon$ значно меншою, ніж в Україні. Так, у США громаду, яка налічує близько 100 тисяч населення, представляють 10 депутатів, які отримують зарплатню, що дорівнює середній зарплаті вчителя [10]. В українських реаліях депутатів на таку кількість населення щонайменше вдвічі-втричі більше. Тож, якщо зменшити чисельність складу місцевих рад (тим більше, що в процесі адміністративно-територіальної реформи в Україні цей процес уже відбувається), а також дати місцевим депутатам достатню фінансову мотивацію їхньої праці, то, як видається, можна розраховувати на те, що люди, які справді хочуть еволюційно-легітимно змінити систему, зможуть присвячувати свій час розвитку громади та підвищувати як рівень захищеності інтересів власної громади, так і в цілому - рівень захищеності національних інтересів і національної безпеки України.

При цьому механізми мотивації професійної роботи місцевого депутата можуть бути різними. Найефективнішим, виходячи з позитивного зарубіжного досвіду, був би компенсаторний. Місцевий депутат міг би отримувати компенсацію не лише за кількість сесійних засідань, а й за роботу в комісіях, депутатських днях чи виїзних засіданнях, тобто за фактично витрачений час на виконання депутатських повноважень. Також, можлива варіативність у питанні компенсації за виконання депутатської роботи в сесійний період, тобто за фактичну діяльність під час голосування винесених у порядок денний питань чи проєктів, які після ухвалення отримують статус рішень відповідної місцевої ради.

Беззаперечним $\epsilon$ й інший висновок: важливо продумати механізми поєднання депутатських функцій із основною роботою, аби виконання 
повноважень депутатів місцевих рад не заважало і не перешкоджало виконанню ними основної роботи, а було гармонійним доповненням до неї. У цьому сенсі корисним $є$ апробований досвід країн, які практикують, аби сесійні та комісійні засідання місцевих рад проводилися виключно в позаробочий час. Таку практику, зокрема, застосовують у США - i це дає змогу будь-якому члену громади відвідувати засідання, а депутатам - без шкоди для основної роботи працювати для блага громади.

Невід'ємним аспектом запропонованого на сьогодні в Україні реформування органів місцевого самоврядування має стати також розробка ефективних механізмів контролю за використанням коштів, які витрачатимуться на компенсацію виконання депутатських повноважень депутатами місцевих рад. При цьому, необхідним $є$ системний підхід до вирішення вказаної проблеми, який передбачатиме внесення відповідних змін і коректив у систему функцій та нормативно-правових актів, що регламентують роботу тих чи інших контролюючих органів і антикорупційних інституцій держави. Звичайно, за теперішніх умов загального зубожіння мільйонів українців і дефіциту бюджетів усіх рівнів вказана проблема $є$ особливо дратівливою, а громадська та суспільна думка в Україні навряд чи готова до таких змін. Але запропоновані зміни - еволюційний шлях, який для будьякої влади $\epsilon$ прагматичніший від революційного, та й, зрештою, він безпечніший, особливо в контексті тих об'єктивних викликів і загроз, що стосуються національної безпеки та можливих геополітичних впливів на регіони нашої держави.
Саме тому, зважаючи на міжнародний цивілізаційний досвід, а також задекларований після Революції гідності вектор руху українського суспільства до європейських цінностей, можна констатувати, що рано чи пізно якісна робота депутатів місцевих рад в Україні буде оплачуватись. Виходячи з цього, досить важливо, щоб Україна якнайшвидше позбулася у самоврядуванні системи депутатського «волонтерства», яке фактично залишилось нам у спадок від тоталітарної радянської держави (СРCP), що може розглядатись як своєрідний атавізм, який тягне Україну назад у тоталітарне минуле, а також як одна із детермінант, що обумовлює існуючий рівень корупції та потенційну загрозу національним інтересам України.

Відмовитися від таких підходів у теперішніх українських реаліях означає піти проти усталеної суспільної та громадської думки. Але владі, яка хоче показати політичну волю піти «подалі від Москви», як основного джерела посягань на національну безпеку України, та наблизитися до апробованих часом цивілізаційних європейських стандартів, не варто, як видається, боятися непопулярних рішень. Більше того, треба вже починати формувати громадську та суспільну думку про те, що депутатське «волонтерство» в управлінській системі - це тимчасовий, більшою мірою не виправданий з точки зору запобіжної антикорупційної практики, спосіб делегування управлінських функцій держави на місцевий рівень.

3 іншого боку, Україні необхідно готувати законодавчу базу для відповідного реформування правової системи з цих питань, а також розро- 
бити комплекс нормативно-правових актів, у тому числі у контексті змісту тих із них, які покликані захищати національні інтереси України. Особливу увагу, як видається, слід зосередити на виробленні механізмів, які би не просто протидіяли (адже протидія - це вже зворотна реакція на чиюсь дію або бездіяльність), а забезпечували ефективну організацію запобіжної діяльності [12], причому як у сфері діянь, потенційно пов'язаних із корупцією, так і у сфері захищеності та зміцнення національної безпеки нашої держави.

Висновки. Враховуючи результати проведеного у цій наукові статті аналізу та сучасні соціальнополітичні та правові реалії, можна констатувати, що боротьбу з корупцією у владі в Україні якраз і варто пов'язати 3 відповідним реформуванням та зміною мотивацій діяльності депутатів в органах місцевого самоврядування. Щонайменше - тоді в інформаційному просторі зникнуть наративи про «наскрізь корумповану владу», а сильна реформована місцева влада неодмінно почне реально впливати та диктувати нові «правила гри» і для носіїв центральної влади, а при цьому знижувати рівень потенційних і реальних загроз для національної безпеки.

Можливо, саме такою і мала би бути кінцева мета децентралізації та адміністративно-територіальної реформи в нашій державі? Адже сьогодні, по завершенні структурних укрупнень громад і районів у процесі реформування, адмінреформа відверто «провисає», і вже практично ніхто з представників влади не може дати чітких відповідей на запитання, яким же має бути її кінцевий результат у організаційній складовій. У той самий час, відповідне ж самоврядне реформування, без сумніву, дасть змогу нейтралізувати (блокувати, усунути, подолати тощо) корупційні впливи на зміст депутатської діяльності на місцевому і регіональному рівнях та зміцнити основи національної безпеки в Україні.

\section{Список використаних джерел}

1. Марко Погуляєвський. Трамп заявив, що призупиняв надання допомоги Україні через «тотальну корупцію». Громадське URL: https://hromadske.ua/posts/trampzayaviv-sho-prizupinyav-nadannya-dopomogi-ukrayini-cherez-totalnu-korupciyu (дата звернення: 23.11.2020).

2. Тимчасовий успіх - Україна в Індексі сприйняття корупції. Transparency International Ukraine: URL: https://ti-ukraine.org/news/tymchasovyj-uspih-ukrayina-vindeksi-spryjnyattya-koruptsiyi-2020/?fbclid=IwAR2FgqXEkN87Dd9kUzvlIrCg-lw1kTCih4D1MY2aJJVknWKBQwcRszI32w (дата звернення: 23.11.2020).

3. Про запобігання корупції: Закон України від 14 жовтня 2014 року №1700-VII. Відомості Верховної Ради (ВВР). 2014. №9. Ст. 2056.

4. Урядовий портал. Єдиний веб-портал органів виконавчої влади України. URL: https://www.kmu.gov.ua/news/250197362?fbclid=IwAR00Fkg_un9a1XhHssxEIUX4yvcV WzH1aYa6D0gd4kyS6eKV2mRlcqNmcM4 (дата звернення: 23.11.2020).

5. Національне агентство 3 питань запобігання корупції. URL: https://nazk.gov.ua/uk/novyny/z-2019-roku-97-osib-prytyagnuto-do-vidpovidalnosti-zaumysne-nepodannya-deklaratsiyi-chy-deklaruvannya-nedostovirnyh-vidomostej-17pryznacheno-pokarannya-u-vyglyadi-pozbavlennya-voli/?fbclid=IwAR0-orC_oDrZWKxm YYVk4j06MgHKp5gz-m9lsYt_VSPb8xDZ7AdsZlncCjk (дата звернення: 23.11.2020). 
6. Кримінальний кодекс: Закон України від 5 квітня 2001 року №2341-III. Oфiційний вісник України. 2001, №21, стор. 1, ст. 920.

7. Про національну безпеку України: Закон України від 21 червня 2018 року. Вiдомості Верховної Ради України. 2018. №31. 241 с.

8. Ірина Федорів. Чому так важко знайти порядних депутатів і як це змінити? Українська правда. URL: https://vybory.pravda.com.ua/articles/2017/11/14/7149512/ дата звернення: 23.10.2020).

9. Запобігання корупції: підручник / Б. М. Головкін, О. Г. Колб, В. Ф. Оболенцев та ін.; за заг. ред.. Б. М. Головкіна. Харків : Право, 2019, 296 с.

10. Ірина Федорів. Як контролюють місцевих депутатів в Америці. Українська правд. URL: https://www.pravda.com.ua/columns/2015/10/28/7086608/ (дата звернення: 23.11.2020).

11. Олена Жежера. Бурмістр Юзефова: Якби поводився, як ваші мери, давно був би на безкоштовному харчуванні. Громада Приірпіння. URL: http://kotsubynske.com.ua/2015/09/30/burmistr-yuzefova-yakby-povodyvsya-yak-vashimery-davno-buv-by-na-bezkoshtovnomu-harchuvanni/ (дата звернення: 23.11.2020).

12. Основи громадянського суспільства та політичних знань. Навчальний посібник. За загальною редакцією проф. В. І. Бортнікова. Луцьк : Вежа-Друк. 2020, С. 429431.

\section{References}

Golovkin, B. M. (Red.). (2019). Zapobigannya korupciyi. Harkiv: Pravo [in Ukrainian].

Bortnikov, V. I. (Ed.). (2020). Fundamentals of civil society and political knowledge. Tutorial. Lutsk: Vezha-Druk [in Ukrainian].

A. Kolb, Doctor of Law, Professor, Honored Lawyer of Ukraine, Professor of the Department of Political Science, Management and State Security of Lesya Ukrainka Volyn National University; ORCID: 0000-0003-1792-4739

O. Pirozhik, Advisor to the Rector of the Academy of Recreational Technologies and Law

\section{Deputy "volunteering" as a corruption factor in local government bodies and one of the threats to the national security of Ukraine}

This scientific article considers issues related to the volunteer activities of deputies of local councils, identifies problems that determine the commission of corruption offenses in this regard, as well as developed appropriate scientifically sound and tested by foreign experience measures to eliminate the causes and conditions, that contribute to this socially dangerous phenomenon. The dialectical interrelation of this type of corruption offenses with the determinants of general corruption is also proved and the necessity of their overcoming is substantiated, taking into account the increased public danger of actions committed by deputies of local councils representing and without using their powers contrary to the law. In addition, this article links corruption offenses that occur during parliamentary «volunteering» with the causes and conditions that give rise to sources of encroachment on national security, in particular, by undermining the authority of the state and local governments of Ukraine as holders of power. in Ukraine, as well 
as reducing the level of protection of national interests in various areas of deputy activity.

Thus, it is stated that there is a complex applied problem that needs to be solved, including at the scientific level. Based on the fact that this problem in this approach has not yet been studied by scientists, and therefore, it is relevant and such that is theoretical and practical in nature, and requires a separate scientific research, including the dissertation level. It is in this context that the content of this scientific article is formed and the arguments that are directly related to this research topic are presented in this regard. It was noted that the methodological basis for the preparation of this work were not only and not so much the relevant work of domestic and foreign experts, including Candidate's and Doctoral dissertations are defended on this topic, as well as modern information sources Internet publications and other similar electronic resources, in which the subject of research is informational and national security of Ukraine. Moreover, this scientific article is also based on the empirical materials collected by its authors on the activities of volunteer deputies and the current state of national security of our state. Based on the results of the analysis, the author's position on the ways and directions of solving existing problems is formulated and the conclusion is made that the fight against corruption in government, as a source of encroachment on national security in Ukraine, should begin with reforming and changing the motivation of local self-government authorities, including in the context of deputy «volunteering».

Keywords: deputy; volunteering; corruption, local governments; informational security; national security; national interests; offense; reforming. 